\title{
河岸強度特性の相違を考慮した 河川地形変遷に関する数値解析的研究
}

\author{
内田 崇浩 1 小村 一郎 2 ・川村 里実 $^{3} \cdot$ 清水 康行4 \\ 1学生会員 北海道大学工学院環境フィールド工学専攻（†060-0808 札幌市北区北十三条西8丁目） \\ E-mail: uchida_dbk88@ec.hokudai.ac.jp \\ 2正会員 北海道大学准教授 工学院 (同上) \\ E-mail: i-kumu2@eng.hokudai.ac.jp \\ 3正会員 寒地土木研究所 寒地水圈研究グループ ( T062-8602 北海道札幌市豊平区平岸1条3丁目 1-34) \\ 4 フェロー 北海道大学教授 工学院（干060-0808 札幌市北区北十三条西8丁目） \\ E-mail: yasu@eng.hokudai.ac.jp
}

\begin{abstract}
河川地形を決定する要因については多くの研究がなされ，様及な観測，実験や解析が行われてきた，そ の中で, 植生が重要な研究対象となってきている. 植生は, 根などの効果により土砂輸送を抑制し, 側岸 や砂州などが固定や, 水路幅の狭小化を引き起こすとされることから, 植生は流況と土砂供給の状態に次 ぐ水路形態を支配する重要な要因であると言われる，Millarの研究では, 河岸強度が植生に依存し, 樹林 化した河川ほど蛇行になりやすいことを示した，本研究では，植生による河岸強化の指標として安息角に 着目し, 既往の研究で示された水路形態の特性が変わる変移点付近の水理条件を用いて数值実験を実施し た所，安息角を変化させることで水路形態に大きな影響があることが示唆された。
\end{abstract}

Key Words : numerical study, vegetation, angle of repose, bed variation, meandering

\section{1. はじめに}

河川地形の，高精度の予測や分類には様々な要因を考慮 する必要がある事は，過去の研究でも述べられている．中 でも植生は，根などの効果により土砂輸送を抑制し，側岸 や砂州などが固定や，水路幅の狭小化を引き起こすとされ ることから，植生は流れ・土砂供給の状態に次ぐ水路形態 を支配する重要な要因であると言われる ${ }^{122}$. 植生が侵入す ることで，河岸強度が強くなり，水路の拡幅を抑制する効 果があるとされ，多くの観測や実験において，それが確認

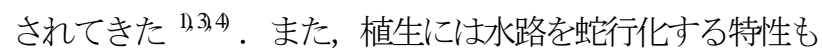
持つことが推則されている. Smith"1実験において粘性土を 用い, 河床材料の特性によって蛇行の形成が可能であるこ とを示したが，地球上において多くの蛇行河川は砂碩床で あり，その汇濫原は植生が繁茂している。碩河床における 蛇行の形成過程は重要な課題である. 蛇行水路の維持の為 には水路短絡の抑制と水路拡幅の減衰などが形成要因とし て挙げられており，そのいずれの効果も持つ植生は，蛇行 河川の維持に大きな役割を持つとされる. Talら 314によると, 植物の発芽・成長が考えられる状態での水路実験において, 水路の側方移動が活発で自然に維持される単列状の蛇行が

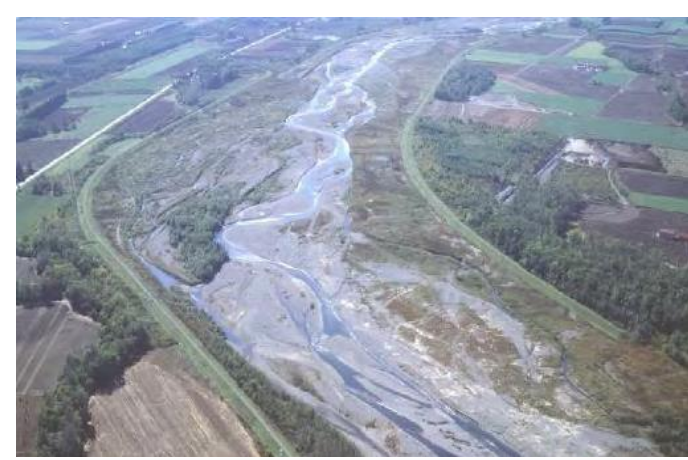

(a) 1978年

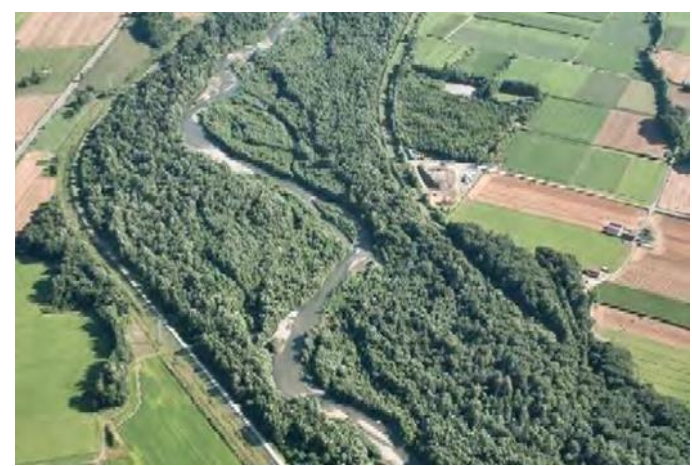

(b) 2010 年

図-1 札内川の変遷 ${ }^{6}$ 
発達することが実証されている.ここにおいて，植生は蛇 行の維持に欠かせない要因であることが示唆されている.

このように，植生が河岸強度や河川地形に対して大きな影 響を持つという事を踏まえ，議論を進めていく.

数值解析における側岸強度を表すパラメータとその役 割について，検証が進められてきた。 Jang ら ${ }^{11}$ は植生に よる側岸の強化に着目して実験を行い，植生密度による 浸食強度を安息角を用いて表した. Mueller らわも, 安息 角を用いて植生の影響度を表し，植生の有無によって河 岸強度が大きく変化することを確認した．別の視点では， 流量や水路勾配など, 種々の水理条件が河川形態を決定 付けていることは古くから推測され，解析がされてきた． Leopold ら ${ }^{8}$ によって示された式は, 勾配と流量から, そ の水路形態を分類するというものであった. その後も, 河床材料の影響を取り込んだ式など, 様々な提案がなさ れてきた. Millar ら `よると, 砂礫床の河川地形は, 水理条件から決定される基準点を境として蛇行河川と網 状河川に分類されるとし，実際に精度の高い分類に成功 している. そこでは, 流量に次ぐ重要な水理パラメータ の一つとして河岸強度の指標である植生が含まれている。 このように, 河岸強度に対して植生の影響を考慮するこ とは重要である. 例として札内川を挙げると, かつての 札内川は洪水の度に䃋河原が更新され十分な水路幅を維 持していたが，平成 7 年の札内川ダム完成以来，年最大 流量の減少などが原因と考えられる広範囲での砂州の樹 林化が進んでおり, 河積容量の低減や急激な環境変化が 懸念され，河道の維持管理において植生が問題視されて いるの.

ところで, 河川計画における数值解析モデルの有用性 は疑いの余地は無いが，こと河岸特性と河床形態の相互 作用のモデル化の妥当性については，十分な検証がなさ れていない，そこで, 本研究は, 河岸強度の指標となる 植生と河床形態分類に関する既往の理論的モデルをとり あげ，これを平面二次元数值解析結果に適用すること で，数值解析モデルによる河岸特性と河床形態の再現 妥当性について考察を試みる. なお，既往の理論的モデ ルとしては, 安息角, 粒径, 流量を与えた場合に河床形 態を, braided, meandering, wandering $の 3$ 形態に分類する Millar らのモデル 9 を取り上げる．植生の影響は安息角 のみに反映されると単純化して議論を進める.

\section{2. 数值実験における水理条件を決定する際に用いた Millar'の研究概要}

Millar は, 図-2 のような台形水路を仮定し, 両岸にお ける掃流力が限界掃流力未満であることや，横断形状が 連続式を満たすことなど, 複数の条件全てを満たす安定

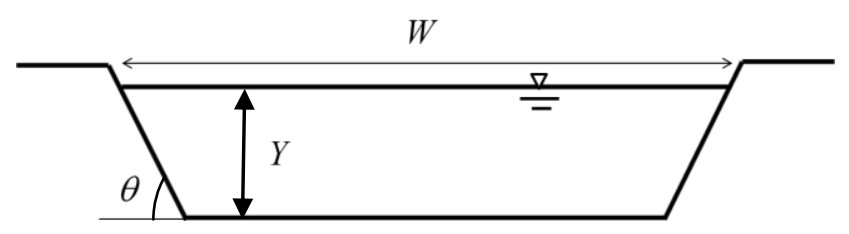

図-2 Millar" によって仮定される台形水路と断面形状

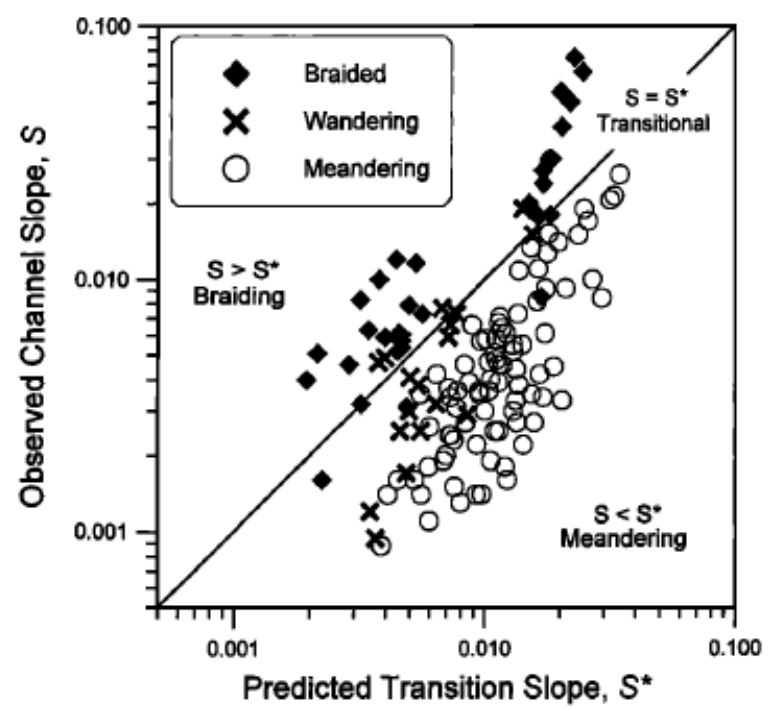

図-3 Millar ${ }^{9}$ による分類式と現地河川の比較(Millar ${ }^{9}$ より引用)

的な水路形状はただ一つに決定されるとし，これをフロ 一チャートを用い，算出した。 ここで算出した断面形状 を Parker ${ }^{10)}$ の式と組み合わせることにより, Millar は, 網 状河川と蛇行河川の分類式を示した. Parkerの式と Millarの式を以降に示す.

まず，Parkerの式であるが，

$$
S^{*} \approx \frac{Y}{W} F_{R}
$$

となる。ここに, $Y$ : 水深, $W$ : 川幅, $F_{R}$ : Fluid 数 $(=U / \sqrt{g Y})$,

$U$ : 平均流速である. 水路勾配 $S *$ *゙であるとき, 蛇行 河川と網状河川の分岐点となると述べている．続い て, Millarの式については, 例として, $D_{50}=.075 \mathrm{~m}$, $\phi^{\prime}=30^{\circ}$ の場合について示すと,

$$
S^{*}=0.000237 D_{50}^{0.61} \phi^{1.75} Q^{-0.25}
$$

となる. ここに, $D_{90}$ : 平均粒径 $(\mathrm{m}), \phi^{\prime}$ :安息角 (degrees), Q: 流量 $\left(\mathrm{m}^{3} / \mathrm{s}\right)$ である. 安息角 $\phi$ 'は植生の影響を表すパラメー 夕としてを用いられている. $S>S^{*}$ となる河川で網状水 路の形成が推則され， $S<S^{*}$ となる河川では蛇行水路の形 成が推則されるとした。 
式(9)を実河川に適用した場合の結果は，図-3 に示されて おり, 閾值となる $S^{*} \approx S$ を境界とし, 蛇行河川と網状河 川に良好に分類される.

\section{3. 計算モデルの概要}

\section{(1) 基礎式}

本研究における数值解析モデルは平面二次元モデルを採 用している．流れの支配方程式は，連続式と浅水流方程式 を用いる。

$$
\frac{\partial h u}{\partial t}+\frac{\partial(h u)}{\partial x}+\frac{\partial(h v)}{\partial y}=0
$$

$$
\begin{aligned}
& \frac{\partial(h u)}{\partial t}+\frac{\partial\left(h u^{2}\right)}{\partial x}+\frac{\partial(h u v)}{\partial y} \\
& =-g h \frac{\partial H}{\partial x}-C_{d} u \sqrt{u^{2}+v^{2}}+\frac{\partial}{\partial x}\left(h v_{t} \frac{\partial u}{\partial x}\right)+\frac{\partial}{\partial y}\left(h v_{t} \frac{\partial u}{\partial y}\right)
\end{aligned}
$$

$$
\begin{aligned}
& \frac{\partial(h v)}{\partial t}+\frac{\partial(h u v)}{\partial x}+\frac{\partial\left(h v^{2}\right)}{\partial y} \\
& =-g h \frac{\partial H}{\partial y}-C_{d} v \sqrt{u^{2}+v^{2}}+\frac{\partial}{\partial x}\left(h v_{t} \frac{\partial v}{\partial x}\right)+\frac{\partial}{\partial y}\left(h v_{t} \frac{\partial v}{\partial y}\right)
\end{aligned}
$$

ここに, $(x, y)$ : 計算空間の空間座標, $t:$, 時間, $h$ : 水深, $(u$, $v)$ : 水深平均流速ベクトルの $(x, y)$ 方向成分, $g$ : 重力加速度, $H$. 水位, $C_{d}$ : 河床抵抗係数, $v_{t}$ : 渦粘性係数である. 乱流モ デルはゼロ方程式モデルを用いる.

また，本研究では平衡流砂モデルを用いて河床変動を 評価する. 流砂は掃流砂のみを対象とし, 掃流砂量は芦 田・道上式 11)で評価している.

$$
\begin{aligned}
& \frac{\partial z}{\partial t}+\frac{1}{1-\lambda_{b}}\left(\frac{\partial q_{b x}}{\partial x}+\frac{\partial q_{b y}}{\partial y}\right)=0 \\
& q_{b}=17 \tau_{*}^{3 / 2}\left(1-\frac{\tau_{*_{c}}}{\tau_{*}}\right)\left(1-\sqrt{\frac{\tau_{*_{c}}}{\tau_{*}}}\right) \sqrt{s g d^{3}}
\end{aligned}
$$

ここに，z河床高， $\lambda_{b}$ : 河床材料の空隙率， $q_{b}: x$ 方向の流砂量 $q_{b y}: y$ 方向の流砂量, $\tau_{*}$ : 無次元掃流力, $\tau_{*_{c}}$ : 無次元限界掃 流力, $s$ : 流砂の比重, $d$ : 流砂の粒径である. 無次元限界 掃流力は岩垣式 ${ }^{12)}$ より求める.

なお，Millar式に基づいて数值解析モデルの評価を行 うことを本研究の主要な目的としている. Millarの式で は抵抗等は考慮されていないため，安息角以外の影響は， 植生抵抗も含め, 考慮しないこととした.

\section{(2) 斜面崩落モデル}

本研究では，河岸強度を表すパラメータとして，安息

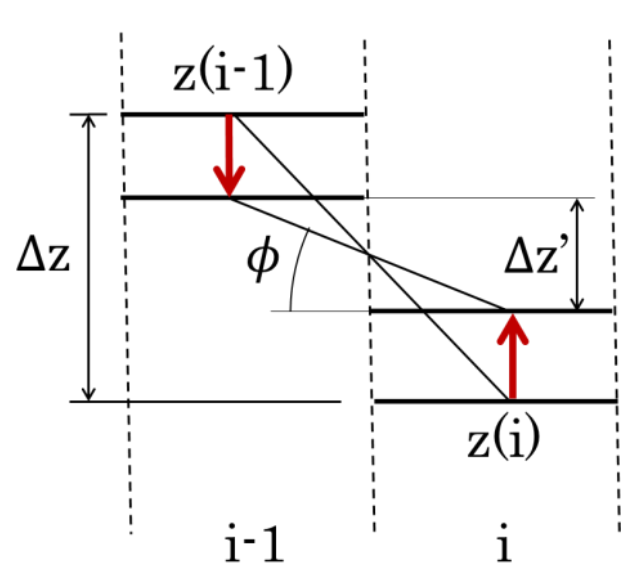

図-4 斜面崩落の模式四

角 $\phi$ ’を用いる. 斜面崩落は安息角 $\phi$ によるものとし, 斜面の勾配が $\phi$ ’り大きくなった場合，斜面崩落が発 生するものとした．上部が斜面が崩れたことによる河床 低下，下部が崩落土砂の堆積による河床上昇が生じ，変 化後の勾配が $\phi$ になるものとした. 斜面崩落の模式困 を図-4に示す．また，斜面崩落が生じた隣接する 2 点間 における河床高の変化については次のように表される.

$$
\begin{aligned}
& z(i, t+\Delta t)=z(i, t)+\frac{1}{2}\left(\Delta z-\Delta z^{\prime}\right) \\
& z(i-1, t+\Delta t)=z(i-1, t)-\frac{1}{2}\left(\Delta z-\Delta z^{\prime}\right)
\end{aligned}
$$

ここに， $\Delta \mathrm{t}$ : 微小時間変化であり，他の変数については 図-4に示すこととする. 実現象では水没部とそれ以外 で安息角は異なると考えられるが，本計算においては Millar式との整合性を考慮して，本計算においては全計 算区域について，安息角を一定とした.

なお，数值解析の実行には河川数值計算共通プラット フォームである $\mathrm{iRIC}^{13)}$ のソルバーNays $2 \mathrm{D}$ に, 若干の変 更を加えて用いている.

\section{4. 数值実験の計算条件}

数值実験に用いた水路は水路幅が $210 \mathrm{~m}$ ，水路長が $1200 \mathrm{~m}$ である.また，初期低水路は直線台形水路を設定 する. 低水路の河床幅は $18 \mathrm{~m}$, 水路の深さは $1.25 \mathrm{~m}$ とし, 斜面勾配を $40^{\circ}$ とした。計算格子数は $800 \times 140$ 個である。 計算領域の上下流端には周期境界条件を課した。 なお, 水路長が計算結果及ぼす影響については今後検討が必要 である．数值実験の各種条件は，表-1 に示す，更に，算 出した $S^{*}$ 值を表-2 に示す. 本研究においては，河岸 強度による河川形態の特性の違いを示すことに重点を置 
表-1 数值実験の計算条件

\begin{tabular}{ccccc}
\hline Run & $\begin{array}{c}\text { Angle of repose } \\
\left({ }^{\circ}\right)\end{array}$ & $\begin{array}{c}\text { Discharge } \\
\mathrm{Q}\left(\mathrm{m}^{3} / \mathrm{s}\right)\end{array}$ & $\begin{array}{c}\text { Mean diameter } \\
\mathrm{d}(\mathrm{mm})\end{array}$ & $\begin{array}{c}\text { Slope } \\
(\%)\end{array}$ \\
\hline 1 & 30 & 70 & 75 & 1.0 \\
2 & 40 & 70 & 75 & 1.0 \\
3 & 50 & 70 & 75 & 1.0 \\
4 & 30 & 100 & 75 & 1.0 \\
5 & 40 & 100 & 75 & 1.0 \\
6 & 50 & 100 & 75 & 1.0 \\
7 & 30 & 100 & 100 & 1.0 \\
8 & 40 & 100 & 100 & 1.0 \\
9 & 50 & 100 & 100 & 1.0 \\
\hline
\end{tabular}

いたため，安息角を変化させた計算条件設定となってい る. また，初期台形水路における水深は $70 \mathrm{~m}^{3} / \mathrm{s}$ のケース で $0.9 \mathrm{~m}, 100 \mathrm{~m}^{3} / \mathrm{s}$ のケースで $1.1 \mathrm{~m}$ であり，初期の水路は 低水路内に限定される。 しかし，いずれのケースでも時 間の経過に伴い，高水敷において水路の存在が確認され た。なお，安息角を $30^{\circ}$ とした条件では，初期河岸勾 配が $40^{\circ}$ と設定されているため，計算初期に河岸の崩 落が生じるが，長期的な計算結果においてはその影響は 小さいと考えられる.

\section{5. 数値実験の結果と考察}

\section{(1) 評価方法}

河川地形の比較のために，平均水深と平均水路幅を用 いる. 平均水深は, 水深が $0.075 \mathrm{~m}$ 以上のセルを抽出し, その箇所の平均を取るものとする．また，平均水路幅に ついても水深が $0.075 \mathrm{~m}$ 以上の箇所の水路について，平 均值を算出した

また，Braided Index によって水路の網状の度合を評価 することとする. Braided Index はいくつかの算定方法が 提案されてきている. 本研究では, Hong ら ${ }^{14}$ が示した 算定式 $B I_{T 3}$ によって求めることとする．算定式を以下に 示す.

$$
B I_{T 3}=N_{L} \text { perXS }
$$

ここに， $N_{L}$ : 横断面と水路の接点の個数，XS: 横断面であ る。河川地形の例を図-5 に示寸．例えば，赤線の横断面 では $N_{L}=3$ である. このように横断面と水路との接点数 を $N_{L}$ とし， $N_{L}$ の横断面当りの平均值を Braided Index と している. また，計測する 2 横断面間の距離は $30 \mathrm{~m}$ と した.
表-2 Millar式による計算結果の推測

\begin{tabular}{cccc}
\hline Run & $\begin{array}{c}\text { Slope } \\
S\end{array}$ & $\begin{array}{c}\text { Calculated } \\
S^{*}\end{array}$ & Predicted \\
\hline 1 & 0.01 & 0.0065 & $\mathrm{~B}$ \\
3 & 0.01 & 0.0130 & $\mathrm{M}$ \\
4 & 0.01 & 0.0059 & $\mathrm{~B}$ \\
6 & 0.01 & 0.0119 & $\mathrm{M}$ \\
7 & 0.01 & 0.0076 & $\mathrm{~B}$ \\
9 & 0.01 & 0.0136 & $\mathrm{M}$ \\
& & \multicolumn{2}{c}{ M : Meandering } \\
& & \multicolumn{2}{c}{ B : Braided }
\end{tabular}

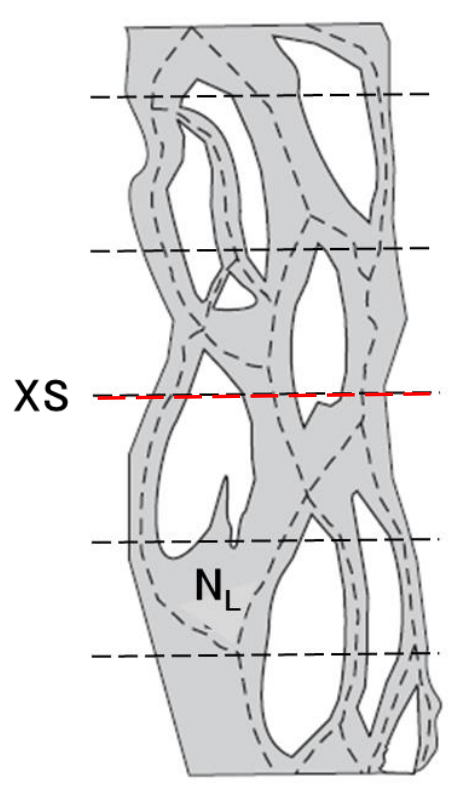

図-5 Braided Index の変数説明図 (Egozi ら ${ }^{15)}$ より引用)

\section{(2) 数值実験の結果}

\section{a) 流量 Q=70m³ $/ \mathrm{s}$ のケースについて}

図-6に, Run 1 と Run 3 の水深コンター図を示寸. 図 は，計算開始加 4000 時間と 6000 時間経過後を取り出 したものである. Run 1 では水路の拡幅した状態が維持 されているのに対し，Run 3 は水路が纏まっているのが 確認できる. 図-7には，河川地形の数值上の結果を示寸， 図-7(a)は平均水路幅の時間推移，図-7(b)は平均水深の時 間経過による推移を表したものである，安息角の効果が 数值上にも表れており，安息角が大きいほど水路幅が小 さく水深が大きくなるという傾向を示した。この結果か ら，Run 1 Run 3 の水理条件においては，Millarの式によ る分類が有効であることを示唆している.

\section{b) 流量 Q=100m³ $/ \mathrm{s}$ のケースについて}

図-8に，Run4 と Run6の水深コンター図を示す。図 
$\mathrm{T}=4000 \mathrm{hrs}$.

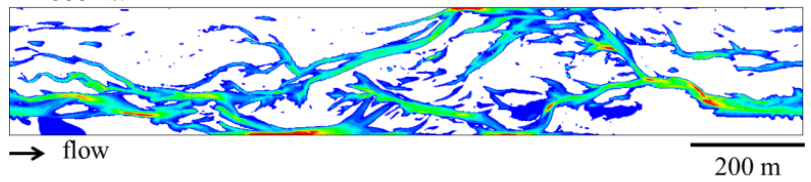

$\mathrm{T}=6000 \mathrm{hrs}$.

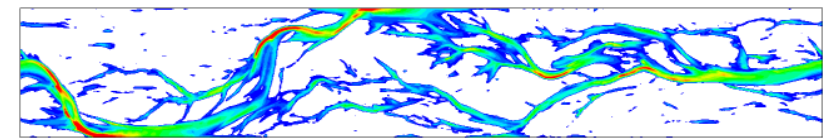

(a) $\operatorname{Run} 1\left(\phi^{\prime}=30^{\circ}\right)$ の水深コンター図

\section{$\mathrm{T}=4000 \mathrm{hrs}$}

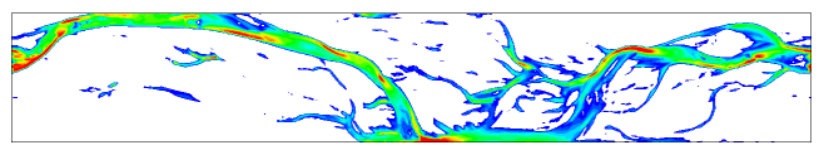

\section{$\mathrm{T}=6000 \mathrm{hrs}$}

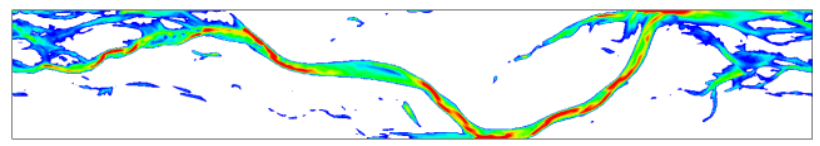

(b) $\operatorname{Run} 3\left(\phi^{\prime}=50^{\circ}\right)$ の水深コンター図

\begin{tabular}{llllllll}
0.0500 & 0.329 & 0.607 & $0.880^{\circ}$ & 1.10 & 1.44 & 1.72 & 2.00 \\
\hline
\end{tabular}

図-6 Run 1 と Run 3の水深(m)コンター図

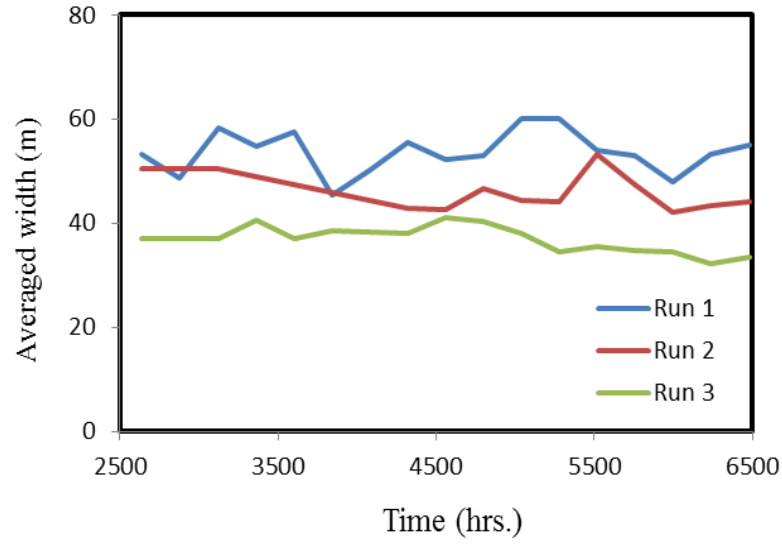

(a) 平均水路幅の推移

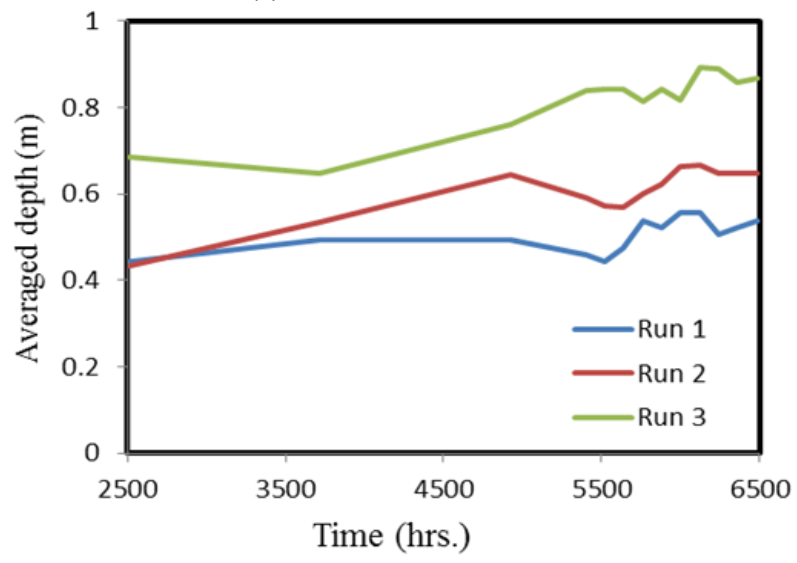

(b) 平均水深の推移

図-7 Run 1から Run3の水路形状の変遷

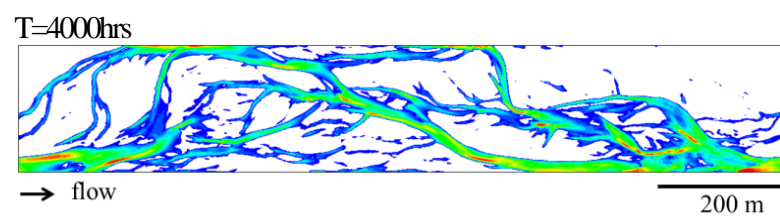

$\mathrm{T}=6000 \mathrm{hrs}$

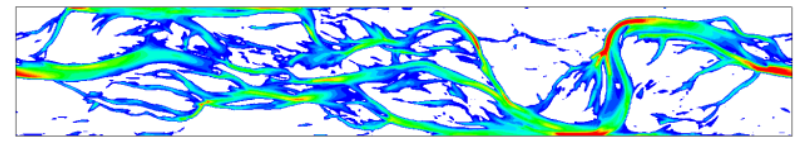

(a) $\operatorname{Run} 4\left(\phi^{\prime}=30^{\circ}\right)$ の水深コンター図

$\mathrm{T}=4000 \mathrm{hrs}$

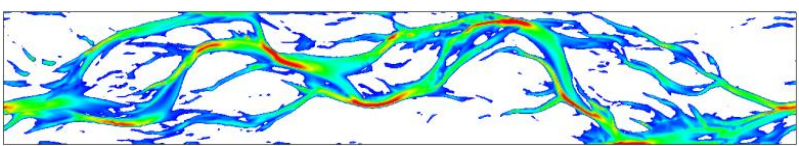

$\mathrm{T}=6000 \mathrm{hrs}$

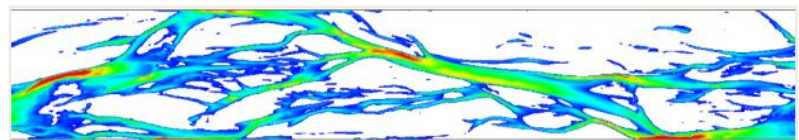

(b) Run6( $\left.\phi^{\prime}=50^{\circ}\right)$ の水深コンター図

$\begin{array}{llllllll}0.0500 & 0.329 & 0.607 & 0.880 & 1.10 & 1.44 & 1.72 & 2.00\end{array}$

図-8 Run4 と Run6の水深(m)コンター図

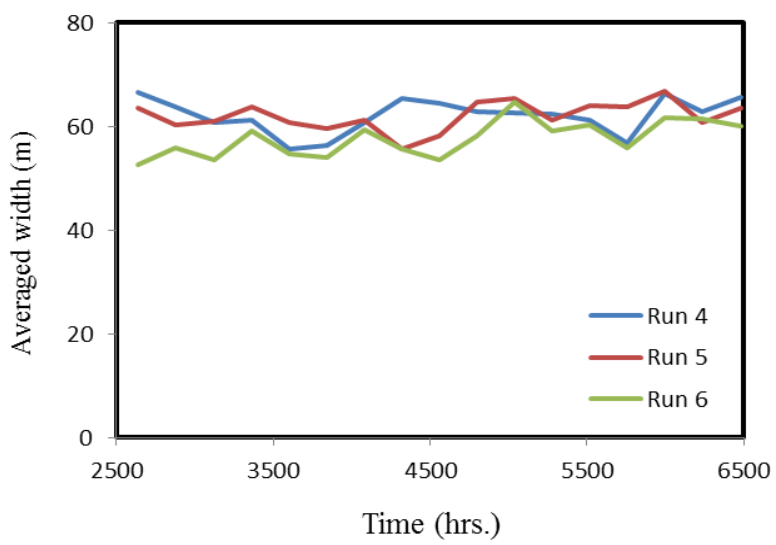

(a) 平均水路幅の推移

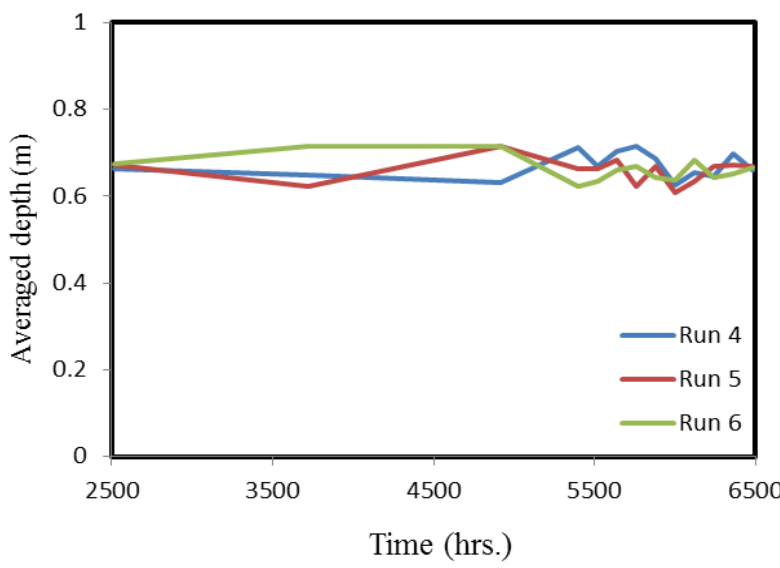

(b) 平均水深の推移

図-9 Run4から Run6の水路形状の変遷 


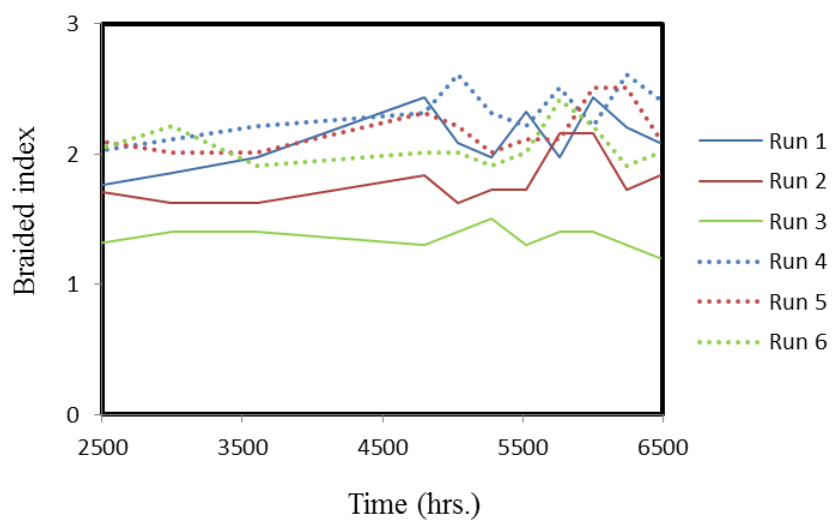

図-10 Braided Index $の$ 変遷

計算開始から 4000 時間と 6000 時間経過後を取り出した ものである. Run 4 と Run 6 間の水路形態を，コンター 図上から比較することは難しい. どちらのケースに おいても水路は拡幅した状態が維持されている．図-9(a) は平均水路幅の時間推移, 図-9(b)は平均水深の時間経過 による推移を表したものである. 水深・水路幅ともに, 明確な差は数值上にも表れていない. この結果から， Run 4〜Run 6 の条件では安息角による影響がほとんど見 られないことが分かる.

\section{c) Braided Index による評価}

Run 1 Run 6 の計算結果を，前述の Braided Indexによっ て評価した，それを図-10 に示寸．平均水深や平均水路 幅の傾向と同様の傾向が見られた. Run 1 Run 3 では, 安息角が小さいほど, Braided Index は大きな值を取った. Run 4 Run 6 では, その網状化の度合に明確な差は生じ なかった。

\section{d) 流量 Q $=100 \mathrm{~m}^{3} / \mathrm{s}$, 粒径 $100 \mathrm{~mm}$ のケースについて}

ここまで, Millar式における流量と安息角について検 討してきたが，Millar 式の平面 2 次元モデルへの適応性 をより明確にするために, 粒径についての検討も行う.

Run 1〜Run 6は寸べて平均粒径 $d=75 \mathrm{~mm}$ で行っているが, ここでは $d=100 \mathrm{~mm}$ で計算を行った.

図-11に, Run 7 と Run 9 の水深コンター図を示す. 図 は, 計算開始から 4000 時間と 6000 時間経過後を取り出 したものである. Run 1 と Run 3程に明確ではないもの の，安息角による水路形態の違いが確認できる. 図-12 には, 河川地形の数值上の結果を示寸. 図-12(a)は平均 水路幅の時間推移，図-12(b)は平均水深の時間経過によ る推移を表したものである.

\section{(3) 数値実験の考察}

\section{a)安息角の影響に関する考察}

前述のように，Millar 式において，安息角は植生によ る側岸強度の指標として与えられており，本研究はそれ に従い各種水理条件を決定した。
$\mathrm{T}=4000 \mathrm{hrs}$

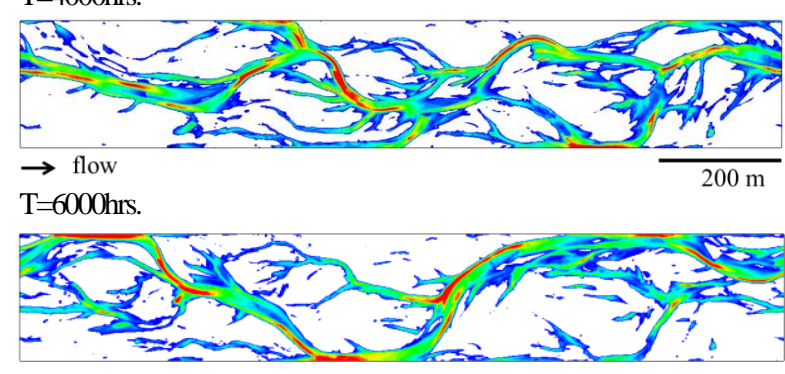

(a) $\operatorname{Run} 7\left(\phi^{\prime}=30^{\circ}\right)$ の水深コンター図

$\mathrm{T}=4000 \mathrm{hrs}$

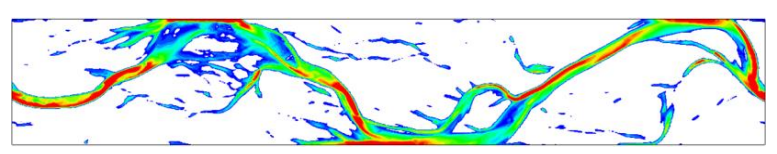

$\mathrm{T}=6000 \mathrm{hrs}$.

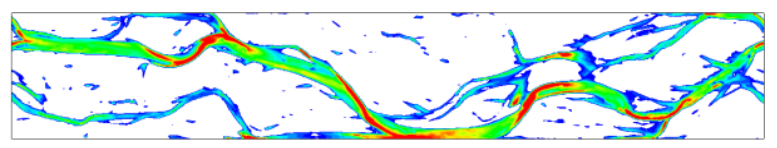

(b) $\operatorname{Run} 9\left(\phi^{\prime}=50^{\circ}\right)$ の水深コンター図

$\begin{array}{llllllll}0.0500 & 0.329 & 0.607 & 0.880^{\circ} & 1.10 & 1.44 & 1.72 & 2.00\end{array}$

図-11 Run7と Run9の水深(m)コンター図

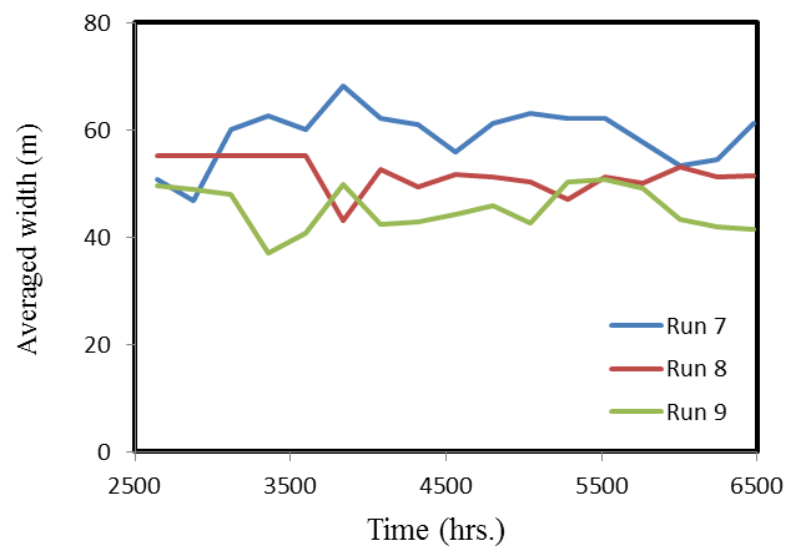

(a) 平均水路幅の推移

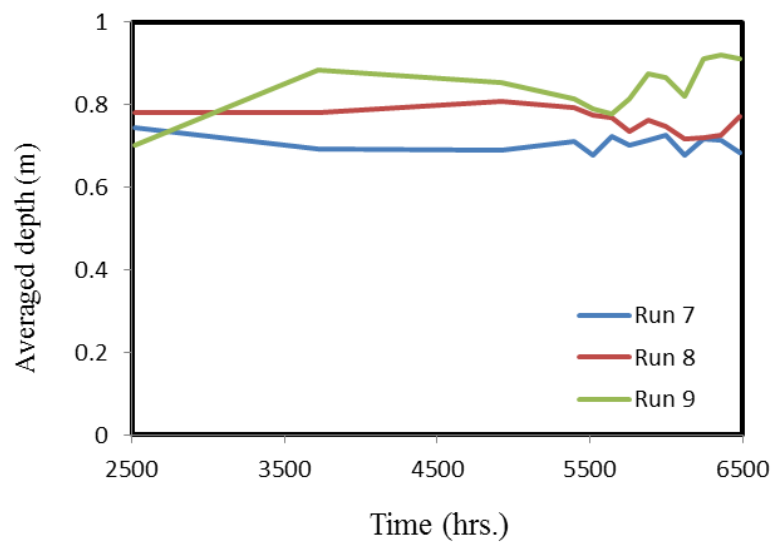

(b) 平均水深の推移

図-12 Run7から Run9の水路形状の変遷 


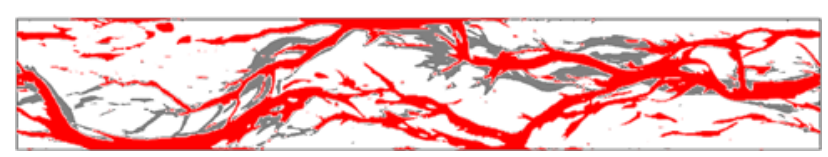

(a) $\operatorname{Run} 1\left(\phi^{\prime}=30^{\circ}\right)$

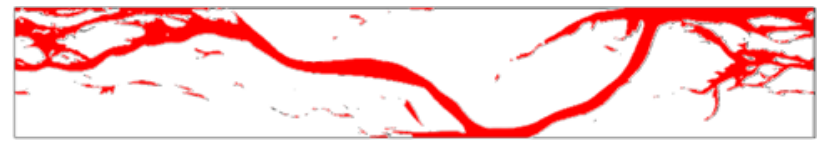

(b) $\operatorname{Run} 3\left(\phi^{\prime}=50^{\circ}\right)$

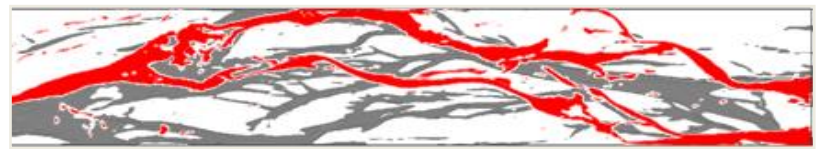

(c) $\operatorname{Run} 6\left(\phi^{\prime}=50^{\circ}\right)$

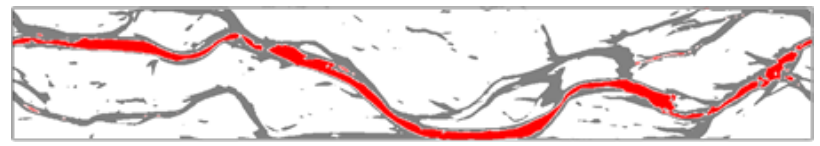

(d) $\operatorname{Run} 9\left(\phi^{\prime}=50^{\circ}\right)$

図-13 限界掃流力に達している箇所の比較 $(\mathrm{T}=6000 \mathrm{hrs}$.) 灰色 : 水路位置, 赤色 : 限界掃流力に達している箇所

流量が $70 \mathrm{~m}$ ³ $\mathrm{s}$ の場合, 安息角によってその水路形態 に大きな影響が見られた．安息角 $\phi^{\prime}=30^{\circ}$ のケースでは, 水路の分裂が至るところで発生していることが図-6(a)で 示されている，安息角 $\phi^{\prime}=50^{\circ}$ のケースでは，図-6(b)に 示すように，水路幅の拡幅が抑制され，比較的緾まった 水路形状が得られた。このことは，安息角が側岸強度の 指標としての十分に機能していることを示唆している.

流量が $100 \mathrm{~m}^{3} / \mathrm{s}$ の場合, 安息角の違いが計算結果に及 ぼす影響は極めて小さくなった．このことは，河岸上に 水流が無い場合と比較して, オーバーフローにより河岸 低下に対する掃流力の影響度が高まる一方で，斜面崩落 する土砂量が少なくなったことが原因として推測される.

\section{b) 限界掃流力が水路に及ぼす影響についての考察}

Run 1 やRun4などのように, 複数の水路が維持されて いる要因を検証することを考え，各 Run における掃流 力の状態を可視化した．それらを図-13 に示す．図では, 赤に塗られた部分が限界掃流力以上の掃流力を持ってい ることを示している. 図-13(a)は, Run 1 の計算結果であ るが，限界掃流力以上の掃流力を持つ水路が複数存在し ていることが見て取れる，一方で，図-13(b)に示される Run 3 の結果は, 支配的な水路は全体を通じてほぼ 1 本 である. 水路幅の増加と水路分裂とが密接な関係である ことは推測できることから, Run 3 は安息角の効果によ って水路の拡幅が抑制されており，これが結果として水 路分裂の抑制にも繋がったのではないかと推測される.

Run 6 の結果を示した. 図-13(c)では, 流量が大きいため, 前述のように安息角の影響がほとんど表れておらず，複 数の水路が水路全体を覆っている. Run 9 の結果を示し た図-13(d)からは，粒径を大きくしたことに伴う掃流力 の減少によって再び，限界掃流力以上の掃流力を有する 水路がほぼ 1 本となっている.

この結果から, 複数の水路が維持され続けるには、土 砂移動が活発に起こるような断面が複数個必要であるこ とが示唆される.

\section{c)Millar の理論と計算結果に対する考察}

Millar による分類式は, 河川形状を理想的な台形水路 を仮定した場合の分類式であるが，流量 $70 \mathrm{~m}^{3} / \mathrm{s}$ の計算 結果の比較からは, Millar らの式は, 平面二次元モデル においても，ある程度成立することが示唆される，その 一方で, 流量が大きくなった場合, Millar の式によって 推測される河川形態と計算結果が示寸河川形態の傾向は 異なっいていた.

まず，Millar 式の仮定では高水敷へのオーバーフロー は考慮していないことを踏まえ, 予測と解析の結果が異 なってしまった原因を考察する，流量が小さい場合，高 水敷へのオーバーフローは確認されたが頻度としては多 くはないため, 平面二次元モデルにおいても台形水路の 仮定が有効であると考えられる，しかし，流量が大きい 場合, 水路からのオーバーフローの頻度が高まることで その影響が顕著となり, Millar 式の仮定と乘離してしま うため, 計算結果に対する Millar 式との整合性が失われ たと推測される. 別の見方をすれば，通水部が低水路内 に限定されるような水理条件における数值解析において は, 安息角が水路に及ぼす影響が相対的に大きく,

Braided と Meanderingの差が明白に生じやすいことを示唆 している.

\section{6. おわりに}

本研究では, 植生の影響として側岸強度に着目し, Millar 式をもとに計算条件を設定し計算を行った，その 結果として，以下のような結果を得られた.

1) Millar 式は, 河川において理想的な台形水路を仮定 した河川形態の分類式であるが，流量が比較的小さい 場合には平面二次元モデルにおいても河床変動形態の 分類に有効である可能性が示唆された．また, Millar の理論が成立する条件としては, 高水敷へのオーバー フロー頻度が少なく, 台形水路の仮定は維持されこと が必要であると推測された。

2) 複数の水路が維持され続けるには、その水路が土砂 移動が活発で支配的な断面である必要性を示唆した。

3）長時間の解析では高水敷へのオーバーフローはどの ような条件でも起こりうることから，植生抵抗を加え れば，より Millar の理論式に近い水路形態が得られた 可能性が高い. 今後の課題としたい. 
1) C.-L. Jang, Y.Shimizu : Vegetation effects on the morphological behavior of alluvial channels, Journal of Hydraulic Research, Volume 45, Issue 6, pp.763-772, 2007.

2) Simon, A. and Collison, A.J.C : Quantifying the mechanical and hydrologic effects of riparian vegetation on streambank stability, EarthSurface Processes and Landforms 27, 527-546, 2002.

3) M. Tal, C. Paola : Effects of vegetation on channel morphodynamics: results and insights from laboratory experiments, Earth Surface Processes and Landforms Volume 35, Issue 9, pp. 1014-1028, 2010.

4) M. Tal, C. Paola : Dynamic single-thread channels maintained by the interaction of flow and vegetation, Geology, v. 35, no.4, pp. 347-350, 2007.

5) Smith CE. 1998. Modeling high sinuousity meanders in a small flume. Geomorphology 25: 19-30.

6) 札内川技術検討会 : 札内川の現状と課題, 2011.

7) Mueller ER, Pitlick J. 2005. Morphologically based model of bed loadtransport capacity in a headwater stream. Journal of GeophysicalResearch 110: F02016, doi:10.1029/2003JF00017.

8) Leopold, L. B., and M. G. Wolman, River channel patterns : Braiding, Meandering and straight, U.S. Geol. Surv. Prof. Pap., 262-B, pp39-85,
1957

9) Millar RG. 2000. Influence of bank vegetation on alluvial channel patterns. Water Resources Research 36(4): 1109-1118.

10) Parker, G., On the cause and characteristic scales of meandering and braiding in rivers, J. Fluid Mech., 76, 457-478, 1976

11)芦田和男，道上正規，移動床流れの抵抗と掃流砂量に関す る基礎的研究，土木学会論文集，第 208 号,pp. 59-69, 1972

12)岩垣雄一 : 限界掃流力の流体力学的研究, 土木学会論文集, 第 41 号, pp.1-21, 1956.

13) http://i-ric.org/ja/introduction

14) Hong, LB \& Davies, TRH. 1979. A study of stream braiding. Geological Society of America Bulletin 90(Part II): 1839-1859.

15)Egozi, R \& Ashmore, P. 2008. Defining and measuring braiding intensity. Earth Surface Processes and Landforms Earth Surf. Process. Landforms 33, 2121-2138.

(2014. 6. 20 受付)

\title{
NUMERICAL STUDIES ON BED VARIATIONS CONSIDERING CHARACTERISTICS OF BANK STRENGTH
}

\author{
Takahiro UCHIDA, Ichiro KIMURA, Satomi KAWAMURA and Yasuyuki SHIMIZU
}

This study examined the morphological behavior of the bed in an open channel flow with bank strength effects by means of a depth-averaged two-dimensional numerical model. We simulated the river morphodynamics under various angles of repose in order to examine whether the aforementioned relations between the angle of repose and characteristics of river morphology can be reproduced numerically. We employed a computational model with depth-averaged two-dimensional shallow flow equations and an equilibrium bedload sediment transport model. In order to take into account the effect of angle of repose, a bank failure model is also incorporated. The numerical results showed that general characteristics of the bed morphology simulated by the present model are in compatible with the features pointed out in the previous papers. Namely, if the angle of repose is larger or smaller, the river becomes meandered or braided, respectively. The present computational results are also compared with the theoretical results by Muller. The agreements between the computations and the theory were generally good. The present computations, not only support the previous empirical and theoretical results on river morphology depending on angle of repose, but also show that the present computational model is a powerful tool to predict river morphology under effects of vegetation. 